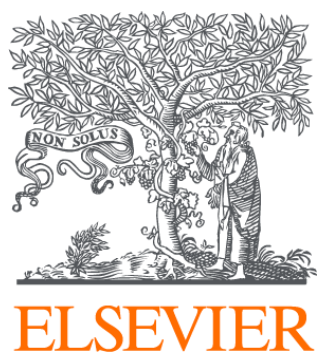

Since January 2020 Elsevier has created a COVID-19 resource centre with free information in English and Mandarin on the novel coronavirus COVID-

19. The COVID-19 resource centre is hosted on Elsevier Connect, the company's public news and information website.

Elsevier hereby grants permission to make all its COVID-19-related research that is available on the COVID-19 resource centre - including this research content - immediately available in PubMed Central and other publicly funded repositories, such as the WHO COVID database with rights for unrestricted research re-use and analyses in any form or by any means with acknowledgement of the original source. These permissions are granted for free by Elsevier for as long as the COVID-19 resource centre remains active. 


\title{
Religion and the state in an episodic moment of COVID-19 in Ghana
}

\author{
Charles Prempeh \\ Faculty of Divinity, University of Cambridge, United Kingdom
}

\section{A R T I C L E I N F O}

\section{Keywords:}

Religion

Law

Faith

Prayer

COVID-19

Church

\begin{abstract}
A B S T R A C T
The goal of this paper is to discuss the role religions are playing to stem the tide against the spread of coronavirus (COVID-19) in Ghana. Focusing on the ubiquity of religions in Ghana, the paper argues that religious experts deploy their ability to invoke the transcendental being to compel adherents to comply with the lockdown rules, as well as follow precautionary measures to fight the virus in Ghana. The paper also maintains that the state has, in the face of the current crisis, passed a law that could be inimical to the future of religious freedom in the country. Methodologically, I draw on critical reflections on electronic and social media reports about religion and humanitarian services in Ghana to argue that religions are bridging the mundane and spiritual gaps to aid the state, while the state is also creatively engaging religions to invest in prayers and also pass laws that are potentially inimical to the future of religious freedom.
\end{abstract}

\section{Introduction}

The threats that are hovering over the world about the spread of coronavirus (COVID-19) has shaken the foundation of the world to the extent that nations around the world have had to adopt measures including lockdowns to contain the spread of the virus and also save lives. The crisis threatens to throw the region of sub-Saharan Africa off its stride, reversing the development progress of recent years. Furthermore, by exacting a heavy toll, destabilising livelihoods, and damaging business and government balance sheets, the crisis could retard the region's growth prospects in the years to come (IMF, 2020, p. 1). The severity of the impact of COVID-19 is such that it has not fully disclosed the extent of its destructive potential. It has confounded the idea that various media, intellectuals, politicians and international financial institutions made that Africa was on the move as the new frontier of the capitalist expansion; an Africa on the path to "emerging" with growth rates that are the envy of the northern countries (Various co-signatories, 2020). The COVID-19 has revealed the challenges besetting the health structures and infrastructures, and complex military-security relations in Ghana. At the time of writing (April 26, 2020), Ghana had recorded a total of 1550 with 155 recoveries and discharged and 11 deaths (GHS, 2020).

As the virus threatens to exact a heavy toll on the human race, one of the institutions of societies - religion - has been deployed as a strategic resource to fight the virus. The deployment of religion in Ghana's religious constituency of about 90 percent faithful to Christianity, Islam, indigenous religions, and other Eastern religions such as Hinduism and
Buddhism is part of the attempts at bridging two spheres - the physical and the metaphysical in fighting a pandemic that is throwing the world out of its comfort zone. The goal of my paper is to understand how the COVID-19 is transforming religious activities, forcing some religious groups to extend their frontiers to include sharing food, which until this perilous time was considered mundane. The paper also examines how COVID-19 is defining the state-religion relationship, as the political elites invite religious leaders to invest in prayers, alongside enforcing precautionary measures to overcome the damaging effect of the virus. More importantly, the paper looks at the future of state-religion relations and the future of religious freedom in Ghana.

The world is grappling with a virus that some world leaders have rhetorically declared an "invisible" enemy (Cathey, 2020). While the world has experienced similar or worse cases than the COVID-19, such as the influenza of 1919 (Jones, 2020), the current virus appears to have startled the world, because it defies the fawning hope invested in technology. The outbreak has put technology on a contradictory trajectory on the one hand, some nations, like China, have employed artificial intelligence and robust technology to minimise the spread of the virus. On the other hand, the technological advances in travelling that have contributed to the shrinking of the world in the popular jargons of globalisation contributed to the virus that began in Wuhan, China in November 2019, to soon become a global issue by February and March 2020. As at the time of writing, no nation had yet succeeded in developing a vaccine that would overcome this novel virus. ${ }^{1}$ In the face of exasperation over the perceived difficulties technology has encountered

E-mail address: prempehgideon@yahoo.com.

1 Currently, a vaccine has been found that is considered largely efficient in saving lives. 
in dealing with an "invisible" enemy, conspiracies about the virus keep making rounds in the world. Some of these conspiracies have blamed China for supposedly creating the virus to pave the way to their rising to become the next superpower in global politics. In Ghana, there are some who are convinced that Dr Thomas Fauci, Bill Gate and his company created the virus as part of their efforts to depopulate the world. While some may squirm at the credibility and rationality of these conspiracies, they are part of the human imaginative efforts at making sense of a virus has been unprecedented since the end of the influenza of 1919.

In the face of the conspiracies and counter-conspiracies is a real fear that human beings are losing control of the world. Since the industrial revolution of the eighteenth and nineteenth centuries, the twentieth and twenty-first centuries have seen the world making unprecedented strides in overcoming some of the basic challenges of human existence - famine, diseases, and wars (Harari, 2016). In all this, what technology is yet to overcome is bad science, of which the possibility of a biological weapon is a menacing threat. For example, one of the conspiracies of COVID-19 is the possibility of it being a biological weapon against humanity. In sum, the illusions of technological self-sufficiency and the suspicion that COVID-19 could be a biological weapon, which coalesced in humans not being in control have reified the fear of most people. But the base of my argument is that the rapidity with which COVID-19 is spreading and the danger it portends to life has brought in religion into the public sphere as an expression of the political limit and the awareness of human finiteness and the inexorable limits to their powers, and the consequent effort to find a coherent answer to reconcile them to their human condition (Bell, 1977, p. 447).

This article draws from available electronic and social media reports and narratives on how religions are reinforcing their relevance in the face of COVID-19. I depend on these sources because virtually all the media houses in Ghana have social media handles where they report their news (alongside the "old' media - television, radio and newspaper). Not all churches publicise their charity work, so the paper could not cover them. Through the publication of charity work in the event of COVID-19, the religious groups register their legitimacy to contribute to public discourses, as well as contest the emerging debate that religious groups are doing less to advance the development of Ghana. Also, since the religious groups get funding largely from their congregants, advertising their charity work online is one way of demonstrating the use to which they put offering, tithe, and financial contributions. The paper is divided into four sections. The first section explores how religious groups in Ghana are investing in prayers to combat the spread and impact of the COVID19. The second section discusses how religious groups are extending their frontiers to incorporate mundane (ordinary) practices of providing food to their people and health supplies to some health facilities in Ghana. The third section discusses how religions are making sense of the lockdown and redefining religious practices to alleviate the anxiety of religious adherents as a result of the COVID-19. The fourth section analyses how a law that was passed in the heat of the COVID-19 will potentially shape the future of religious freedom in Ghana.

\section{Investing in the rituals of prayer: religious unity and division in the face of COVID-19}

In this section, I analyse how the Ghanaian political elites have made recourse to religion to contain the havoc COVID-19 is wrecking on the country. More specifically, I look at how faith-based organisations are responding to the needs of the state and persons on the margins of society. I argue that, in the face of COVID-19, as a global pandemic, the political elites and the Ghanaian community are bridging binaries between religion and politics to secure the interest of the state. This falls in line with one of the importance of religion as having the capacity to inspire hope in the face of perplexity (Hasson-Ohayon \& Braun, 2009). At a time when economies of the world are crushing and when social and physical distancing are undermining one of the key features of the human being as social and gregarious (Berger, 1969: 7), religion has proven more valuable. Most religious people in Ghana have resorted to prayer and provision of basic items to the needy. This dovetails with an observation that in Ghana, faith healers usually serve as the first point of call for disease curing and prevention for most users (Peprah, 2018, p. 1). Alongside investing in faith healing, prayers remain one of the important outlets available to religious people to understand and seek solace in the face of disaster (Mitchell, 2003). The fundamental importance of prayer in the face of crisis or stress is that it gives the religious person the conviction about the sovereignty of God over challenges, which is expressed in the way religious people relate to their stress or anxiety: it is all for the best; ultimately God is in control, and that God is supporting him or her through the problem (Loewenthal, 2000, p. 34). Through prayers, adherents of the various faiths in Ghana (and the world) connect with God to face lived challenges. The investment in prayer is part of religious people expressing their dependence on God, believed to be sovereign and in charge of his creation. More specifically, it demonstrates the dualistic and holistic perspectives that some religious constituencies in Ghana hold about the cause of diseases (Owoahene-Acheampong, 1998: 112-137). In many Ghanaian societies, some religious communities have a worldview that assumes mystical causality for diseases that appear to defy any known cure (Asamoah-Gyadu, 2013: 76). This mystical causality is based on the belief in a world that is suffused with spirits who criss-cross the boundaries of the physical and the material (Asamoah-Gyadu, 2013: 47). The fusing of the physical and the material allows some religious experts to perform rituals to avert and contain diseases. This partly explains why there was a resurgence of Pentecostalism in the Gold Coast in the 1920s following difficult moments of the 1918-1919 influenza which killed 60, 000 people (Mohr, 2011; Patterson, 1983, p. 18).

Apart from Ghana, some leaders of the world are also investing in prayers. Thus, while other jurisdictions in the west may not share the same worldview with most of the people in Ghana, some world leaders, including Donald Trump, have invested in prayers, as he devoted the national Sunday prayer to fight against the virus, alongside injecting millions of dollars into fighting the pandemic in the United States of America (Casiano, 2020). In his call on Americans to pray for the nation, he tweeted: "We are a country that, throughout our history, has looked to God for protection and strength in times like these ...., No matter where you may be, I encourage you to turn towards prayer in an act of faith. Together, we will easily PREVAIL!" (Casiano, 2020, emphasis in the original text). In the United Kingdom (UK), the Archbishop of Canterbury, Justin Welby, declared Mothering Sunday (March 22, 2020) as a National Day of Prayer and action (Welby, 2020). This declaration did not suffice, as Susan Hawkes, a resident of Kent, UK, wrote a petition for the Prime Minister, Boris Johnson, to declare a National Day of Prayer against the COVID-19. In the petition, she indicated that, "Our country is in crisis due to the coronavirus; our government is doing the best it can, but surely we need to call upon God for help" (Hawkes, 2020). The invocation of God into the fight against COVID-19 comes against the grain of two societies that have deeply become secularized and tend to have a rationalistic perspective of life.

In Ghana, on March 19, 2020, the president of the Republic, Nana Addo Dankwa Akufo-Addo, called for a prayer meeting that witnessed the congregation of some of the leading clerics of the various Christian denominations in Ghana. There was a range of representatives from the historic churches and Pentecostal/Charismatic Christians (collectively constituting the Christian Council of Ghana, Pentecostal and Charismatic Council), and the Ghana Catholic Bishops' Conference represented by Archbishop John Bonaventure Kwofie of Accra and Fr. Andrew Campbell, SVD, Parish Priest of Christ the King Parish, Accra. The Pentecostal churches were represented by Apostle Eric Kwabena Nyamekye, the chairman of the Church of Pentecost, the largest Pentecostal denomination in Ghana, constituting about ten percent of Ghana's population (Markin, 2019, p. 1), and Archbishop Duncan-Williams, the head of the Charismatic Christianity in Ghana.

In the course of introducing the prayer session, which was held at the 
Jubilee House, the seat of the Presidency in Accra, the president rhetorically said,

These are not ordinary times and at such times in a country whose population is predominantly Christian, we must seek the face of the one true God for healing and restoration. I have called you to this prayer meeting for us to join together and pray to the Almighty God to protect our nation, heal this land and save us from this pandemic. We are also putting into practice the hope of the words in the Holy Scriptures in James 5:14 and I quote, 'If anyone among you sins let the elders of the church pray over them and anoint them with oil and a prayer offered in faith will raise him. I am confident that this morning's prayer, which will be offered in faith will help heal our nation and will help raise Ghana and I believe profoundly that we the Ghanaian people, with faith in the Almighty, will overcome this challenge. This too shall pass.

On March 20, 2020, a day after the president of Ghana had led Christians in prayer, the vice president of the country, Dr Mahamadu Bawumiah, who is a Muslim, also led a breakfast prayer meeting with key national Muslim clerics, including the National Chief Imam, Sheikh Osmanu Nuhu Sharubutu, Maulvi Muhammed bin Salih (the head of the Ahmadiyya Movement in Ghana); Alhajj Umar Ibrahim Imam (head of the Ahlu Sunnah wal Jaamah Muslims). The Tijaniyya and the Shi'a Muslims were also represented. In the course of his prayers, the representative of the Ahmadiyya Muslims recited from Qur'an 112, which reads: "Say: He is God, the One! God, the eternally Besought of all! He begets not nor was he begotten. And there is none comparable to Him!" With this text, he charged the Muslim clergy who had gathered at the Jubilee House, the seat of government, to beseech God in dealing with the COVID-19 pandemic.

Given that the representation of Muslims at the prayer breakfast transgressed inter-sect religious differences, more specifically Islam, it unveils how the crisis of COVID-19 is contributing to bridging religious gaps in the Muslim community in Ghana. This is precisely because the current crisis does not speak any denominational differences. It, therefore, required the harvesting and harmonising of the spiritual fronts of the Muslim community to fight it. I argue that the Muslim community in Ghana have "temporarily" suspended their denominational and sectarian differences to join the nation in launching a fight against the COVID-19. Thus, in a very rare occurrences in the Fourth Republic, all the Muslim clergies said "Aameen" to each other's prayer, the atmosphere breathing unity into the Muslim community in Ghana. This development is against the background that intra-Islamic religious conflict between the Ahmadiyya movement, which has been in Ghana since the 1920s, and the sonamed orthodox Muslims has been raging for decades since the 1930s in Ghana (Azumah, 2000, p. 24). The two main sects in Islam have sharp differences over some peculiar doctrines of the Ahmadiyya movement, such as the prophethood of Ghulam Ahmad, the founder of the religion.

Given the controversy over the person of Ghulam Ahmad, the orthodox Muslims refer to the Ahmadiyya as apostate Islamic movement (Ahmed-Rufai, 2002: 106). The movement's Christology - which admits the natural death of Jesus Christ - is also at variance with the beliefs of the "orthodox" Muslims. This and other differences have caused a wedge between these two main sects of Islam in Ghana. Beyond the Ahmadiyya-"orthodox" divide, the "orthodox" Muslims have also been sharply divided into some doctrines and practices. The Tijaniyya endorses the mystical and experiential ways of knowing God, while the Ahlu's-Sunnah enjoins the return to the model set by the Prophet and his companions in the first century of the religion (Dumbe, 2019, p. 155). These differences, which inform some ritualistic practices, crystallised in the 1990s when the Tijaniyya and the Ahlu's-Sunnah wa'l-Jama'ah were locked in physical violence that disrupted the peace of some of the Muslim inner-cities in Ghana, including the Zongos (inner-city Muslim communities) in Accra and Kumasi (Mbilah, 1999). The peaceful interaction among the different Islamic denominations and sects, particularly between the Tijaniyya and Ahlu's-Sunnah is diminishing, following the rise of young Muslim scholars who are seeking to bridge the gaps among these groups (Kobo, 2015). While some scholars think that there is an incipient tension in intra-Islamic relations (Yunus, 2019), the outbreak of the COVID-19 pandemic appears to be bridging gaps within Islam, as we see Muslims in some Zongo communities in Accra, including Nima and Maamobi joining hands to provide care for one another.

The unity emerging within the Muslim community also marks the marginalisation of representatives of indigenous and other Eastern religions in Ghana. As the president and his vice solicited the clergies of Christianity and Islam to pray, religious experts of the indigenous religions and other Eastern Religions in Ghana, including Hinduism and Buddhism, were left out. It was the marginalisation of indigenous religious practitioners that partly informed the widespread circulation of video footage on Facebook and WhatsApp on March 26, 2020 of an indigenous religious expert in one of the Akan areas berating the president and the church for submerging Ghana into the current crisis. In anger, the priest who is identified as Nana Nyantakyi blamed the spread of the virus in Ghana because of the nation's neglect of indigenous religions in Ghana. He challenged the state to invite him and other indigenous ritual experts to perform rituals which he believed would end the spread of the virus. ${ }^{2}$ Similarly, in responding to the crisis, William Amuzu Agbodzalo, Senior Panel Member of Zakadza Shrine, popularly known as Nogokpo Shrine, performed rituals to command the virus into the deep waters (River Volta). Following the ritual performance, he asked the river deity to provide them with guidance on how to cope and also predicted that the virus would clear off the shore of Ghana and Africa on April 19, 2020 (Ghanaweb, 2020).

The perceived side-lining of indigenous religious practitioners in the "spiritual crusade" against COVID-19 is not different from what the former president of Ghana, John Evans Atta Mills (2009-2012) who died in office before completing his term, did. He banned at state functions the pouring of libation - an indigenous way of prayer, which involves the practice of calculative pouring of an alcoholic beverage on the ground to call on departed ancestors and deities to help the living and was a necessary condition for the success of every ceremony (Akyeampong, 1995). Libation also marks the transition between private and public episodes, and it is necessary for bridging the gaps between human and the deities and ancestors (Kilson, 1969, p. 166). Banning it, therefore, incurred the anger of some Ghanaians, including Prof Kwame Karikari, the former Executive Director of Media Foundation for West Africa. He criticised President Mills as he pointed out that the truncation of the practice of pouring libation at national ceremonial functions was discriminatory (Modernghana, 2011). While the performance of libation has been restored by the current president, Nana Akufu-Addo, his failure to invite indigenous religious practitioners to officially pray for the nation, was considered an infringement on the old tradition of the performance of libation since the regime of Kwame Nkrumah, Ghana's first president in the 1950s (Botwe-Asamoah, 2005: 22). The perceived official marginalisation of indigenous religions in the "spiritual crusade" against COVID-19 also runs roughshod against the constitutionality of Ghana as a religiously plural country (Nyinevi \& Amasah, 2015).

\section{Engaging the mundane in the face of COVID-19}

In this section, I discuss how religious communities are broadening their reach beyond ritual performances to incorporate humanitarian services and also invest in acts of altruism. Faith-based organisations have played a significant role in providing for persons who become marginalised as a result of conflicts or natural disasters. In Australia, faith-based organisations have played a significant and progressive role that has contributed to a more humane and compassionate asylum policy

\footnotetext{
${ }^{2}$ Given the relative incendiary nature of the comments of the priest, Facebook and WhatsApp pulled down the video barely a week after it was publicised.
} 
(Wilson, 2011). In the face of the political stalemate that plagued Kenya after 2007/2008 elections, faith-based organisations in Kenya became more instrumental in providing diverse forms of practical, emotional and spiritual support to internally displaced persons in Mai Mahiu IDP (Internally Displaced People's) camp (Parsitau, 2011). More specifically, religion provides the meaning that people need to recover from a painful past and current crisis (Horstmann, 2011, p. 515). The challenge that faith-based organisations have mostly faced is how to broaden their humanitarian service to include people who do not share the same faith with them (Horstmann, 2011). While this challenge of transcending religious divide to do good to others is part of religions that lay claim to doctrinal exclusivity, both Christianity and Islam tend to have texts in their scriptures that some of them depend on to broaden the frontiers of their charity work to include non-members. For example, Christians are encouraged to do good to all (Galatians 6:10) and the Muslims are equally enjoined to do same (Qur'an 2:265-266). Through these texts, alongside sermons that provide affirmation, individuals are encouraged to engage in social action and services (Smith, 1996, pp. 10-12). We can appreciate this observation when, in a plea for a donation towards COVID-19 response, the National Catholic Secretariat (NCS) wrote as follows: "In these times of COVID-19 pandemic, there is need for people all over the world and Ghana, in particular, to live exemplary Christ-like lives by extending love, kindness, and care to those who are affected or in the line of high risk to the deadly COVID-19" (NCS, March 2020). The capacity of religion to help people go through difficult and perilous times is the meaning religion provides adherents. Human beings have a predisposition to seek meaning - usually in moments of pain, which appears indispensable (Berger, 1969). Meaning is also central to human existence and religion helps people to make sense of crisis (Park, 2005, pp. 295-314). So, given the fact that religion - sociologically - provides a set of beliefs and practices that focus extensively on the transcendence, religion can provide meaning to people when mundane lives do not fit what is considered normative (Smith 1996: 5-7).

The focus religion places on the transcendental has been deployed to ensure that the frontier of the religion to provide material and nonmaterial resources to persons affected by disaster is broadened to include members (insiders) and non-members (outsiders). Churches and other faith-based organisations have provided meaning that ensures inclusivity in the distribution of aid and resources to persons affected by the COVID-19 in Ghana. As religions define the gaps between what believers "are" and what they "ought" to be, religious adherents are provided with a vision that inspires altruism, which is articulated through songs, rituals, testimonies, and sermons (Smith 1996). In Ghana, people are transgressing social and religious boundaries to provide help for those in need. For example, Elder Peter Kwesi Terkper (Area Deacon of the CoP, Haatso Area, Accra) and his wife, Mrs Joyce Terkper, two church leaders of the Church of Pentecost (CoP), the largest Pentecostal church in Ghana (Markin, 2019, p. 1), on April 19, 2020, issued a letter to their tenants informing them of a rent waiver for three months. The Teshie-Nungua Area of the CoP, in collaboration with the twenty-six districts in the Area, has donated assorted essential food items worth GHC 353,027.00 (about US\$ 62321.13) to the needy and the vulnerable in the church. The Area church has also set up a COVID-19 fund to extend support to the needy and vulnerable, considering the effect of the partial lockdown on them. The Area Head, Apostle Dr Alfred Koduah and his wife gave an amount of GHC 5000.00 [about US\$ 882.7] (Orhin, 2020). The Odorkor Area of the CoP has also donated food items and an amount of GHC 1000.00 (about US\$ 176.53) to some students at the Pentecost University College (PUC) - the CoP's university in Ghana - who are presently on campus (Pentecost News, 2020). On March 30, 2020, The Action Chapel International, the pioneer charismatic church in Ghana, founded by Archbishop Nicholas Duncan Williams in 1979, reached out to over four hundred of its members who needed food (Ghanaweb, 2020). The Presbyterian Church of Ghana also provided free lunch every day for one hundred medical staff working at Greater Accra Regional Hospital (Ridge Hospital), Tema General Hospital, and Ga East
Government Hospital - three designated health centres managing COVID-19 cases in Ghana (George Larbi, 2020). The Islamic NGO, Darul Hadith, located in Accra is also shared foods and other basic needs to Muslims and non-Muslims in Muslim-inner cities in Accra.

On April 16, 2020, the Konongo Area of the CoP also donated medical supplies worth GHC 7000.00 (about US\$ 1235.75) to the Asante-Akim Health Directorate in the Asante Region of Ghana for onward distribution to fourteen public and private health facilities within its administrative enclave and the Divisional Police Office in support of the fight against the COVID-19 virus in Ghana (Pentecost News, 2020). On April 3, 2020, the CoP donated medical supplies to the La Clinic and Raphael Medical Centre in Accra. On March 24, 2020, the CoP headquarters in Accra donated PPE to the Ministry of Health and released twelve vans to the National Commission for Civic Education (NCCE) for nationwide public education as part of the efforts to combat COVID-19. The church also made separate donations to the Komfo Anokye Teaching Hospital and Ho Teaching Hospital. The church also presented PPE to thirteen selected health facilities, namely LEKMA Hospital, Amasaman Hospital, Kaneshie Hospital, 37 Military Hospital, St. John's Hospital, Ga South Municipal Hospital, Tema Polyclinic, Mamprobi Polyclinic, GA East Hospital, Ashaiman Polyclinic, Amanfro Polyclinic, Kasoa New Market Clinic and Oduman Polyclinic (Pentecost News, 2020). On March 24, 2020, the CoP, in partnership with Tobinco Pharmaceuticals donated protective logistics worth GHФ 45,000.00 (US\$ 7933.68) to the Ministry of Health to help in the fight against the virus. The also set aside GHC $100,000.00$ (about US\$17630.39) to support the government of Ghana (Ghanaweb, 2020).

On April 17, 2020, the Ministry to Persons with Disabilities (MPWDs) of the CoP donated assorted food items worth GH\$ 15,160.00 (about US\$ 2676.25) to some persons with disabilities in Accra and Kumasi, two regions in Ghana that were hard hit by the lockdown. The MPWDs is a newly-introduced ministry intervention of the CoP that was birthed as part of the five-year strategic vision of the church known as "Vision 2023". ${ }^{3}$ On April 6, 2020, the Home and Urban Missions (HUM) of the CoP distributed assorted food items to 200 persons some slum communities in the Accra Metropolitan and Kasoa, including persons with disabilities in the wake of the lockdown. The church also provided free meals to 400 mentally challenged people on the streets of Accra, Ashaiman, and Kasoa [in the Central Region of Ghana] (Pentecost News, 2020). On April 17, 2020, the Most Rev John Bonaventure Kwofie, Metropolitan Archbishop of the Catholic Church, Accra, led a delegation and made donations to the Ghana Prisons headquarters as a response to the outfit's call for support amidst the COVID-19 pandemic (Radioangelus, 2020).

On March 27, 2020, the president announced the establishment of COVID-19 Fund to receive contributions and donations from the public to assist the needy and the vulnerable in a crisis. The fund is managed by an independent board of trustees, chaired by Ghana's immediate past Chief Justice, Sophia Akuffo. In response to the announcement, the Apostolic Church, Ghana, a classical Pentecostal church in Ghana, presented a cheque for GH\$70,000 (about US\$ 12341.27) to help government's efforts in dealing with the COVID-19 pandemic in the country. The presentation was led by the Vice President of the church, Apostle Frederick Agyemang and was received at the Office of the President by the Chief of Staff, Mrs Akosua Frema Osei-Opare (Dapatem, 2020). Similarly, the International Central Gospel Church (ICGC), one of the oldest charismatic churches that has been operating in Ghana since the 1980s, contributed GH\$100,000 (about US\$ 17630.39) to support the Trust Fund (Myjoyonline.com, 2020). On April 1, 2020, the Methodist Church Ghana also presented large quantities of hand hygiene materials and

\footnotetext{
3 The MPWD seeks to build a strong ministry to persons with disabilities through effective evangelism and discipleship, as well as create an enabling environment to promote their spiritual, emotional and personal growth to impact the church, their communities, and nations.
} 
cheques totaling GHC 200,000 (about US\$ 35260.78) to four institutions to support the fight against the spread of the COVID-19 pandemic. The beneficiary institutions were the Ministry of Health, Noguchi Memorial Research Institute, the Ghana Prison Service, and Methodist Health Facilities in rural areas (Dapatem, 2020).

\section{Making sense of the lockdown and reconfiguring of religious practice}

In this section, I discuss how religions are making sense of the lockdown and redefining religious practices to alleviate the anxiety of religious adherents as a result of the COVID-19. I argue that the pandemic has affected some of the foundational bases of religious space and orthopraxis. By reimaging the essence of the lockdown, religious communities are collaborating with the state to enforce the protocols about the lockdown. The capacity of religion to ensure compliance to the law is that religious people claim that their laws are the result of a supreme being who created and owns the world and must be respected. Missionoriented religions like Christianity and Islam tend to have imagined and real communities where unity is sustained through members subscribing to the ideals of the religion. As an imagined community, religious adherents are expected to respect the rules and regulations - that are not expected to be challenged because they are believed to flow from a supernatural being - informing and shaping lives in the community. Given the rapid spread of COVID-19 and the resulting imposition of lockdown restrictions - restructuring state's control over movement and social gatherings - most of the religions in Ghana have moved from offline religious activities - preaching and sharing communion - to online services. The malleability and creativity Muslims and Christians - particularly Christians - have demonstrated in deploying digital technology, especially social media handles like Facebook and WhatsApp to continue with the religious community is important for controlling the virus. This transition from offline church services to online services is a continuity rather than a break - in the digitalisation of religion (Campbell, 2013), which has been ongoing since the advent of social media and WhatsApp in Ghana in the beginning of the twenty-first century.

One of the ways religious communities have contributed to the fight against COVID-19 is the deployment of religious text and narratives to request adherents to comply with lockdown norms from the state. On March 28, 2020, following the normative practice (largely recommended by the World Health Organisation) of stemming the tide against the virus, the president of Ghana, Nana Addo Dankwa Akufo-Addo announced a lockdown on the Greater Accra Metropolitan Area and the Greater Kumasi Metropolitan Area from 01:00 (local time). It was to take effect on Monday, March 30, 2020. The logic of the lockdown, which lasted for three weeks until it was lifted on April 19, 2020, was because the COVID19 is caused by a respiratory virus that spreads through direct contact from a cough or sneeze from an infected person. There are some key reasons why the lockdown unsettled most Ghanaians. To begin with, there was the disruption of human sociality. This is because, as human beings with a gregarious instinct it is important have physical contact, including mundane ones like hugging shaking of hands, and kissing. Consequently, restricting social activities was a burden to many Ghanaians. There was also the novelty of the restriction. Since independence, Ghana had not had an instance where people were compelled to stay at home and to avoid social gatherings in the way that the COVID-19 lockdown demanded. Ghana has had about five successful military interventions which centralised power in the military regime. This centralisation of power sometimes led to the violation of the rights of some Ghanaians (Oquaye, 1995). But the nation had hardly experienced a regime where people could not even bury their dead (if the funeral ceremony would involve more than twenty-five people) or even fail to congregate for religious purposes. The closest Ghana, specifically Accra, came to a "mock" lockdown situation was when the Supreme Court of the country was to declare the verdict on the election petition of the 2012 elections (which saw court proceeding dragging for almost a year) on
August 29, 2013. Out of fear of possible eruption of violence, some Ghanaians voluntary locked themselves in their rooms. With the rarity of the COVID-19 and given the predilection of most Ghanaians for a social gathering (including some Ghanaians violating the law on lockdown to satisfy their curiosity), the lockdown came as a challenge to many of them, precisely also because most of them in Accra and Kumasi belong to the informal sector of the economy whose livelihood depends on petty trading. In response, some Ghanaians violated the restriction and were brutalised by the joint police-military team that was ensuring conformity to the lockdown rules.

The recourse to religious texts and narrative is because religion is part of stabilising the anxiety of Ghanaians. As I have stated above, the ability of religion to enforce laws is based on its claims and appeal to authority from a supernatural being that legitimises social institutions - including respect to political authorities - by bestowing on them an ultimately valid ontological status, that is located within a sacred and cosmic frame of reference (Berger, 1969:33). It is from this enablement of religion to sacralise obedience to authority that I discuss how Christians and Muslims endorsed the lockdown. Eric Kwabena Nyamekye, the chairman of the CoP called on the members of the church to comply with the directive of the president to stay at home. As part of ensuring compliance from his constituency and also the larger Christian community, he stated that plagues - such as the COVID-19 - are not foreign to the planet earth because the Bible has records of plagues. He maintained that in Biblical times, when plagues became very tough, what people did was be in a lockdown. He also reproduced the narrative about Noah and the Ark. He maintained that God himself locked the people in the Ark just to prevent them from being drowned. According to him, God never gave the keys to Noah. He, God, locked the Ark himself and opened it when he found it necessary. He also gave an instance about the locking down of Samaria and the locking of the Israelites when the angel of death was to strike in Egypt. He concluded by quoting from the book of Isaiah 26:20-21, part of it reads, "Go, my people, enter your room and shut the doors behind you; hide yourselves for a little while until his wrath has passed by" (Pentecost News, 2020).

The National Chief Imam of Ghana, Sheikh Osman Nuhu Sharubutu also called on Ghanaian Muslims to adhere strictly to the restriction protocols, including the suspension of congregational prayers in mosques, announced by the government to combat the spread of the COVID19. Legitimising the need for Muslims to comply with the directive of the president he said that "the directive is not a departure from Islamic norms. It is grounded on sound Islamic principles and one of them is the love for all, as well as the preservation and protection of life. Muslims have to be well and physically fit to be able to worship Allah well" (Ghanaweb, 2020). And instead of Muslims worrying about the lockdown, he asked them to be thankful to God for sustaining Ghana all this while. Reinforcing the call of the National Chief Imam, his spokesperson, Sheikh Aremeyao Shuib said that Islam is a religion of flexibility in terms of the application of the law (Sharia), moderation, and conceptualisation. In providing an example to support the flexibility of Islam, he said that "though a Muslim is not allowed to take in alcohol, sharia permits a Muslim to take alcohol if it is the only available liquid when one is suffering from massive thirst or dehydration on a desert" (Ghanaweb, 2020). Some Muslims also took to social media to share some Hadith injunctions about what Muslims should do in the face of epidemic or pandemic. These included the one on quarantine which states that, "Run away from leper (the one with contagious ailment) as you would run away from a lion" (Bukhari Vol, 7, Book 71, No. 60) and "The plague (contagion) patient who remains in his home with patience and expectation of reward, knowing that nothing will befall him other than Allah's decree will attain the reward or a martyr (Musnad Ahmad, Shaih and Bukhari, 2829). In terms of social distancing, "Those with contagious diseases should be kept away from those who are healthy (Bukhari, 6771; Muslim, 2221). In terms of staying at home, the Muslims invoked the text, "Those who stay at home to protect themselves and others are under the protection of Allah" (Musnad Ahmed, Saheeh). Finally, in terms of 
using a facemask, they said, "The Prophet while sneezing would cover his face with his hand or with his garment" (Abu Dawud, Tirmidhi, Book 43, Hadith, 2969).

There was also the question of congregational prayer. In this respect, the Muslims quoted the Hadith that reported the Muhammed to have said, "The entire earth has been made a masjid, except graveyards and washrooms" (al-Salaah, 291). But critical was the question of Azan calling Muslims for prayer - which is very central to the daily reinforcement of the central tenets of Islam. With this, the vice president, Mahamud Bawumia, who is also a Muslim, advised Muslims to use social media platforms to announce for Jummah prayers (Friday congregational prayer) in compliance with the government's directive. He supported his recommendation and the need for the lockdown by saying that, "Prophet Mohammed advised that in the event of an outbreak of a plague, people should not leave that particular place (where the plague occurred)" (Ghanaweb, 2020). The suggestion by the vice president that Muslim should use social media to call Muslim for prayers had been made before by Prof Kwabena Frimpong Boateng, Ghana's Minister for Environment, Science, Technology and Innovation in April 2018. Given the challenge of "noise pollution" from some religious freelance preachers who use loudspeakers in the market and transport spaces to preach, Prof. Frimpong Boateng suggested to all religious people to minimise "noisemaking". He suggested Muslims use social media, instead of traditional megaphone to invite Muslims to prayer (Ghanaweb, 2018). The call by the Minister received a quick rebuke from some Muslims in Ghana. The Northerners and Zongos Concerned Youth Association of Ghana and Muslim Broadcast Association demanded the removal of the Minister for making what they considered an incendiary and barbaric statement. The national coordinator of the group and veteran Hausa Broadcaster, Alhaji Haiidu Abubakar Galaxy rebuked the minister by saying, "Azan or call to prayer is a Qur'anic injunction which cannot be changed." The office of the National Chief Imam also rejected the suggestion from the minister (Ghanaweb, 2018). From the suggestion of Prof Frimpong Boateng and what the fact that the Azan is not called in the lockdown areas in Greater Accra and Greater Kumasi, we can see how religion can cohere what appears to be a contradiction. Religions can make changes to incorporate new changes and to also resolve an evolving and emerging crisis. This reflects the dialectic character of religion, where oppositions are explained in ways that shed meaning on difficult situations.

\section{COVID-19 and the future of religious freedom in Ghana}

This section looks at how a law that was passed in the heat of the COVID-19 could potentially reshape the future of religious freedom in Ghana. As religious groups deployed their scriptures to ensure compliance to government's directives, a law has been passed that could potentially undermine religious freedom. The current COVID-19 is a pandemic that warrants the deployment of emergency law to temporarily suspend the rights of Ghanaians. This is because, the virus, constructed as an "invisible war", does not follow any convention of war that has physical and spatial definitions. In other words, it is difficult for nations to be precise about laws that apply to convention wars. It is, therefore, quite appropriate that people have to temporarily give up some of their rights as the state and other stakeholders work to control the virus. This is in accordance with the 1992 Constitution of Ghana Article 31 (9) that maintains that the state of emergency may be declared in a state of natural disaster or any situation that threatens life in Ghana. But in the face of the COVID-19, the government of Ghana has passed the Imposition of Restrictions Act, 2020 (Act 1012), which gives power to the president of Ghana the right to curtail freedoms of Ghanaians to protect life. But in the interest of this paper, the part of the law that I find potentially dangerous to religious freedom is 3(d) which reads that for the purpose of "safeguarding the people of Ghana against the teaching or propagation of a doctrine which exhibits or encourages disrespect for the nationhood of Ghana, the national symbols and emblems, or incites hatred against other members of community" (IRA, Act1012: 3).
This section of the law could be read as a case of government passing a law about state-religion relations, a similitude of which many Ghanaians had protested since 1985. In 1985, the Provisional National Defence Council (PNDC) that metamorphosed into the National Democratic Congress (NDC) in 1992 passed the Intestate Succession Law (PNDCL 111) of 1985. The law was designed to address marital problems, including unequal distribution of properties. Consequently, the law was to provide a uniform intestate succession law that would be applicable throughout the country irrespective of the class of the intestate and the type of marriage that was contracted (Dovlo, 2005, p. 637). But the law, proposing egalitarianism in the sharing of property, infringed on Muslim's customary succession practices that accords with the Sharia that enjoins the "unequal" sharing of property between male and female children (Dovlo, 2005, p. 640). Given the disquietedness Muslims expressed about the law, most of them do not apply the PNDC L111, except in rare cases of family dispute. In June 1989, the PNDC passed the Religious Bodies (Registration) Law of 1989 that required every religious group to register with the National Commission for Culture to control the proliferation of religious bodies and religious activity in Ghana (Quashigah, 1999, p. 589). The law was rationalised on the perception that certain churches were being pushed by some individuals and groups as meeting grounds in furtherance of political schemes to unseat the government (Haynes, 1991, p. 416). The law led to the expelling of the Jehovah's Witnesses and the Church of Jesus Christ of Latter-day Saints (LDS/Mormons) because they were said to be insubordinate to political authority and were dismissive of African culture (Nugent, 1995, p. 188). There was also a ban on two local churches - Nyame Sompa and Jesus Christ of Dzorwulu because their beliefs were considered to be at odds with the state (Oduro-Marfo, 2018). The Christian Council of Ghana and other religious bodies challenged the law and it was eventually repealed when the 1992 constitution came into force. The 1992 constitution 21 (1c) allows for freedom to practice any religion and to manifest such.

Since 2006, there have been calls for the state to regulate the practices of some religious groups. In many cases, individual churches of small and middle-sized Pentecostal and charismatic churches, known as "one-man churches" (Lauterbach, 2017, p. 5) that do not fall under any particular institutional religious bodies have been accused of infringing the rights of some Ghanaians. These church founders claim to have spiritual powers that is embedded in their "show of power" in the ways they relate with their church members. In many instances, social media have been inundated with graphic images of some pastors of these individual churches beating or molesting church members (Ghanaweb, 2018). There are also cases of churches refusing to pay taxes, even though some of them sell anointing oils in church. Some of these church leaders are also accused of flaunting wealth in the face of abject poverty among their church members and some churches are also accused of noise pollution (Ghanaweb, 2019). A few of these church leaders who are labelled as political prophets prophesy about the outcome of political elections and also prophesy about the death of prominent persons in Ghana. For example, Bishop Isaac Owusu Bempah, founder of the Glorious Word and Power Ministry International, has become known for his political prophecies. But he went beyond his reach to prophesy about the death of the National Chief Imam of Ghana, Sheikh Osmanu Nuhu Sharabutu who was a centenarian at the time of the prophecy in December 2018. This prophecy sent some Muslim youth on a rampage and threatened to unsettle the peace of Ghana (Ghanaweb, 2019). In the midst of all this, in May 2019, the Speaker of Parliament of Ghana, Prof Aaron Michael Oquaye, initiated a conversation on how parliament could find ways to regulate religious activities in Ghana (Ghanaweb, 2019). The churches, particularly the Ghana Charismatic Bishop Conference, challenged the right of the state to regulate church or religious activities (Ghanaweb, June 2019). The issue was not discussed in public and went quiet for possible political expedience.

In the face of COVID-19 and away from public scrutiny, the government of Ghana has passed the Imposition of Restrictions Act, 2020 (Act 1012). The law gives the president the power to restrict people's political 
and cultural rights in times of crisis. But the potential danger in the law is that it allows the state to interfere with the religious freedom of Ghanaians. This Act could be abused and used to introduce dictatorial tendencies in a democratic state. Because the law invests both legislative and judiciary powers in the hands of the president, any future president who may not be favourably disposed to a particular religious group could use the law arbitrarily against the group. As it stands now, the law contributes to sacralising the state through the compulsory imposition on Ghanaians to demonstrate loyalty to state symbols. It is possible that the Jehovah's Witnesses, who do not pay homage to state symbols - sing the national anthem, say the national pledge, salute the flag of Ghana - or even join the national security services could be a target for marginalisation. Given the COVID-19 crisis, the state hardly followed due processes which involves broader consultation to rush through a law that is potential harmful to the religious freedom of Ghanaians, guaranteed by the 1992 constitution. This development could be read as the state using power to engage in authoritarian inventions in the life of people that may imperil the basic rights of Ghanaians.

\section{Conclusion}

The paper has looked at how religion is intermeshing with the state to minimise the anxiety that most Ghanaians are going through as a result of the COVID-19. The paper has discussed the reconfiguration of religious beliefs and practices and the employment of religion to enforce compliance to the protocols of COVID-19. But equally central to the paper is the passage of the Imposition of Restrictions Act that may be inimical to the religious freedom of Ghanaians.

\section{CRediT authorship contribution statement}

Charles Prempeh: Conceptualization, Data curation, Formal analysis, Funding acquisition, Investigation, Methodology, Project administration, Resources, Software, Supervision, Validation, Visualization, Writing - original draft, Writing - review \& editing.

\section{Declaration of competing interest}

I do write to declare that the reviewers I selected do not run into any conflict of interest as far as their objectivity in reviewing the article is concerned. I have not sent any of them the article to review before submitting it to you. They are professionals who uphold the integrity of academic honesty.

\section{References}

Ahmed-Rufai, M. (2002). The Muslim Association Party: A test of religious politics in Ghana. Transaction of the Historical Society of Ghana, New Series, N. 6, 99-114.

Akyeampong, E. (1995). Alcoholism in Ghana - a socio-cultural exploration. Culture, Medicine and Psychiatry, 19, 261-280.

Asamoah-Gyadu, J. K. (2013). Spirt and spirits in African religious traditions in Veli-Matti Kärkkäinen. In K. Kim, \& Y. Amos (Eds.), Interdisciplinary and religio-cultural discourses on a spirit-filled world (pp. 41-54). New York: Palgrave Macmillan.

Azumah, J. (2000). Controversy and restraint in Ghana. Transformation, 17(1), 23-26.

Bell, D. (1977). The return of the sacred? The argument on the future of religion. British Journal of Sociology, 28(4), 419-449.

Berger, Peter (1969). The Sacred Canopy: Elements of a Sociological Theory of Religion. New York: Anchor Books.

Botwe-Asamoah, K. (2005). Kwame Nkrumah's politico-cultural thought and policies: An African-centered paradigm for the second phase the African revolution. New York/ London: Routledge.

Campbell, H. A. (2013). Introduction: The rise of the study of digital religionH. A. Campbell (Ed.). . In Digital religion: Understanding religious practice in new world (pp. 1-22). Oxon: Routledge.

Casiano, L. (2020, March 13). Trump declares Sunday a national day of prayer and amid corona virus crisis. Retrieved from https://www.foxnews.com/politics/trump-s unday-national-day-of-prayer.

Cathey, L. (2020, March 17). Trump now calling coronavirus fight a 'war' with an 'invisible enemy. Retrieved from https://abcnews.go.com/Politics/trump-coronavi rus-task-force-economic-public-health-steps/story?id=69646672.
Dapatem, A. D. (April 1, 2020a). COVID-19: Methodist Church Ghana supports govt with cash, other items. Retrieved from https://www.graphic.com.gh/news/general-news/ covid-19-methodist-church-ghana-supports-govt-with-cash-other-items.html.

Dapatem, A. D. (April 6, 2020b). Apostolic church donates GH\$70,000 to COVID-19 fund. Retrieved from https://www.graphic.com.gh/news/general-news/apostolic-churchdonates-gh-70-000-to-covid-19-fund.html.

Dovlo, E. (2005). Religion in the public sphere: Challenges and opportunities in Ghanaian lawmaking, 1989-2005 (Vol. 3, pp. 629-658). Brigham Young University Law Review.

Dumbe, Y. (2019). Islamic polarisation and the politics of exclusion in Ghana: Tijaniyya and Salafist struggles over Muslim orthodoxy. Islamic Africa, 10, 153-180.

Ghana Health Service. (2020, April 20). Ghana's situation routine surveillance. Retrieved from https://www. ghanahealthservice.org/covid19/.

Ghanaweb. (2018, April 11a). Use WhatsApp not speakers for 'call to prayer' - minister to Muslims. Retrieved from https://www.ghanaweb.com/GhanaHomePage/NewsArchi ve/Use-WhatsApp-not-speakers-for-call-to-prayer-Minister-to-muslims-642249.

Ghanaweb. (2018, April 13b). Muslim groups demand removal of Prof. Frimpong Boateng for 'call to prayer' comment. Retrieved from https://www.ghanaweb.com/GhanaHo mePage/NewsArchive/Muslim-groups-demand-removal-of-Prof-Frimpong-Boatengfor-call-to-prayer-comment-642864.

Ghanaweb. (2019, December 20a). Court orders ICGC, Crossroad Church to pay GHS3K for noise making. Retrieved from https://www.ghanaweb.com/GhanaHomePage/Ne wsArchive/Court-orders-ICGC-Crossroad-Church-to-pay-GHS30K-for-noise-making819973.

Ghanaweb. (2019, January 2b). Machete-wielding Muslim youth vandalise Owusu Bempah's church. Retrieved from https://www.ghanaweb.com/GhanaHomePage /NewsArchive/Machete-wielding-Muslim-youth-vandalise-Owusu-Bempah-s-church $-712373$.

Ghanaweb. (2019, June 4c). You can't legislate our faith - charismatic Churches. Retried from https://www.ghanaweb.com/GhanaHomePage/NewsArchive/You-can-t-le gislate-our-faith-Charismatic-Churches-752011.

Ghanaweb. (2019, May 30d). Parliament to decide on regulation of churches. Retrieved from https://www.ghanaweb.com/GhanaHomePage/NewsArchive/Parliament-todecide-on-regulation-of-churches-750581.

Ghanaweb. (2020, April 2a). Lockdown: Action Chapel provides food for church members. Retrieved from https://www.ghanaweb.com/GhanaHomePage/NewsA rchive/Lockdown-Action-Chapel-provides-food-for-church-members-911413.

Ghanaweb. (2020, March 16b). National Chief Imam calls on Muslims to adhere to government's coronavirus protocols. Retrieved from https://www.ghanaweb.com /GhanaHomePage/NewsArchive/National-Chief-Imam-calls-on-Muslims-to-adher e-to-government-s-coronavirus-protocols-895963.

Ghanaweb. (2020, March 25c). Church of Pentecost donates logistics to Ministry of Health to combat coronavirus. Retrieved from https://www.ghanaweb.com/Ghana HomePage/NewsArchive/Church-Pentecost-donates-logistics-to-Ministry-of-Health -to-combat-coronavirus-904171.

Ghanaweb. (2020, March 28d). Coronavirus will disappear April 19 - Nogokpo shrine. Retrieved from https://www.ghanaweb.com/GhanaHomePage/NewsArchive/Coron avirus-will-disappear-April-19-Nogokpo-Shrine-906718.

Harari, N. Y. (2016). Homo deus: A brief of tomorrow. London: Harvil Secker.

Hasson-Ohayon, I., Braun, M., Galinsky, D., \& Baider, L. (2009). Religiosity and hope: A path for women coping with a diagnosis of breast cancer. Psychosomatics, 50(5), $523-533$.

Hawkes, S. (2020, March 24). Call upon the rt hon Mr Boris John for national day of prayer. Retrieved from https://www.change.org/p/boris-johnson-call-upon-boris-joh nson-for-national-day-of-prayer. (Accessed 19 April 2020).

Haynes, J. (1991). Human rights and democracy in Ghana: The records of the Rawlings' regime. African Affairs, 90(360), 407-425.

Horstmann, A. (2011). Ethical dilemmas and identifications of faith-based humanitarian organizations in the Korean refugee crisis. Journal of Refugee Studies, 24(3), 513-532.

International Monetary Fund. (2020). Regional economic outlook: Sub-Saharan Africa COVID-19: An unprecedented threat to development. Washington: International Monetary.

Jones, S. D. (2020). History in a crisis - lessons for covid-19. The New England Journal of Medicine, (382), 1681-1683.

Kilson, M. (1969). Libation in Ga ritual. Journal of Religion in Africa, 2(2), 161-178.

Kobo, O. (2015). Shifting trajectories of salafi/ahl-sunna reformism in Ghana. Islamic Africa, 6(1-2), 60-81.

Larbi, G. (2020, March 25). Presbyterian Church of Ghana donates to corona virus medical team. Retrieve from https://pcgonline.org/2020/03/25/presbyterian-ch urch-of-ghana-donates-to-corona-virus-medical-team/.

Lauterbach, K. (2017). Christianity, wealth, and spiritual power in Ghana. Cham: Palgrave Macmillan.

Loewenthal, M. K. (2000). The psychology of religion: A short introduction. Oxford: One World.

Markin, J. A. (2019). Transmitting the spirit in mission: The history and growth of the Church of Pentecost. Oregon: Wipf \& Stock.

Mbilah, A. J. (1999). The causes of present day Muslim unrest in Ghana. United Kingdom: PhD Dissertation submitted to the University of Birmingham.

Mitchell, T. J. (2003). Prayer in disaster: Case study of Christian clergy. Natural Hazards Review, 4(1), 20-26.

Modernghana. (2011, April 22). Ban' on pouring of libation at the state functions discriminatory - Prof. Kwame Karikari. Retrieved from https://www.modernghana .com/news/325868/ban-on-pouring-of-libation-at-state-functions.html.

Mohr, A. (2011). Capitalism, chaos, and Christian healing: Faith tabernacle congregation in southern colonial Ghana, 1918-26. The Journal of African History, 51, 63-83. 
Myjoyonline. (2020, April 2). International central Gospel church donates $\$ 100 \mathrm{~K}$ to covid-19 Trust fund. Retrieved from https://www.myjoyonline.com/news/national /international-central-gospel-church-donates-\%C2\%A2100k-to-covid-19-trust-fund/. Nugent, P. (1995). Big men, small boys and politics in Ghana. London: Pinter.

Nyinevi, Y. C., \& Amasah, N. E. (2015). The separation of church and the state under Ghana's Fourth Republic. Journal of Politics and Law, 8(4), 283-292.

Oduro-Smith, S. (2018). Eyes on you while your eyes are on God: State surveillance of religion in Ghana under the Provisional National Defence Council regime. Surveillance and Society, 16(94), 399-409.

Oquaye, M. (1995). Human rights and the transition to democracy under the PNDC in Ghana. Human Rights Quarterly, 17(3), 556-573.

Orhin, G. I. (April 18, 2020). Teshie-Nungua area donates items worth GHC 353,027.00 to the vulnerable. Retrieved from https://thecophq.org/news/teshie-nungua-area-donat es-items-worth-over-gh\%C2\%A2-353000-to-the-vulnerable/.

Owoahene-Acheampong, S. (1998). Inculturation and African religion: Indigenous and western approaches to medical practice. New York: Peter Lang Publishing, Inc.

Park, L. C. (2005). Religion and meaning. In R. F. Paloutzian, \& C. L. Park (Eds.), Handbook of the psychology of religion and spirituality (pp. 295-314). New York and London The Guilford Press.

Parsitau, S. D. (2011). The role of faith and faith-based organisations among internally displaced persons in Kenya. Journal of Refugee Studies, 24(3), 493-512.

Patterson, K. D. (1983). The influenza epidemic of 1918-19 in the Gold Coast. The Journal of African History, 24(4), 485-502.

Pentecost News. (2020, April 16a). Konongo area donates to asante-akim health directorate, police service. Retrieved from https://thecophq.org/news/konongo-are a-donates-to-asante-akim-health-directorate-police-service/.

Pentecost News. (2020, April 17b). Odorkor Area donates to PUC students. Retrieved from https://thecophq.org/news/odorkor-area-donates-to-puc-students/.

Pentecost News. (2020, April 17c). The Church of Pentecost donates relief items to persons with disabilities. Retrived from https://thecophq.org/news/the-church-of-pe ntecost-donates-relief-items-to-persons-with-disabilities/.
Pentecost News. (2020, April 6d). The Church of Pentecost donates medical supplies to the La Clinic. Raphal Medical Centre. Retrieved from https://thecophq.org/news/the-ch urch-of-pentecost-donates-medical-supplies-to-la-clinic-raphal-medical-centre/.

Pentecost News. (2020, March 30e). Comply with lockdown directive - Apostle eric Nyamekye to Ghanaians. Retrieved from https://thecophq.org/news/comply-with-lo ckdown-directive-apostle-eric-nyamekye-to-ghanaians/.

Peprah, P., Gyasi, M. R., Adjei, P. O., Agyemang-Duah, W., Abalo, E. M., \& Kotei, J. N. A. (2018). Religion and health: Exploration of attitudes and health perceptions of faith healing users in urban Ghana. BMC Public Health, 18(1358), 1-12. https://doi.org/ 10.1186/s12889-018-6277-9

Quashigah, E. K. (1999). Legislating religious liberty: The Ghanaian experience. Brigham Young University Law Review, 2, 589-606.

Radioangeluscom. (2020, April 17). COVID-19: Accra archdiocese responds to Prisons service's call. Retrieved from https://radioangelus.com/covid-19-accra-archdiocese -responds-to-prisons-services-call/.

Smith, C. (1996). Introduction: Correcting a curious neglect, or bringing religion back. In C. Smith (Ed.), Disruptive religion: The force of faith in social movement activism (pp. $1-25)$. New York and London: Routledge.

Various co-signatories. (2020, April 16). COVID-19: An open letter from african intellectuals to africa's leaders: 100 leading academics and writers call on leaders to govern with compassion and see the crisis as a chance for a radical change of direction. Retrieved from https://africanarguments.org/2020/04/16/coronavirus-o pen-letter-african-intellectuals-africa-leaders/.

Welby, J. (2020, March 17). Coronavirus: Archbishops call for national day of prayer and action. Retrieved from https://www.archbishopofcanterbury.org/news/latest-news/ coronavirus-archbishops-call-national-day-prayer-and-action.

Wilson, E. (2011). Much to be proud of, much to be done: Faith-based organisations and the politics of Asylum in Australia. Journal of Refugee Studies, 24(3), 548-564. 